of post-traumatic stress disorder affecting more than half the adult population in some areas of East Africa has been adduced. How to begin to cope with that mental health burden is an urgent question for those countries affected and for the international community of psychiatrists with an interest in the region. What resources are available, or could be made available, to alleviate the suffering of these people? Dr Kigozi is involved in a mental health and poverty project that has produced a detailed account of services and need in Uganda, in collaboration with the WHO (see http:// workhorse.pry.uct.ac.za:8080/MHAPP/public/index_html); it is to be hoped similar reports - serving as the basis for action in adjacent countries - could be prepared too.

Finally, we move across the Atlantic to Mexico and the concerns expressed by Shoshana Berenzon and colleagues that the extreme inequity of income distribution in Latin
America is responsible for engendering mental health disorders. After Brazil, Mexico has the largest economy in Latin America and is undergoing rapid development, yet one in six of the population lives in extreme poverty, without easy access to sanitation or drinking water, and many of these people are in urban areas. The reason for much mental illness, according to the surveys reviewed by the authors, is the relative socioeconomic status of the sufferer, who feels unable or unwilling to seek professional help - even if that help is potentially available. The authors point out that there may be quite a discrepancy between the perceived needs of the population suffering from the consequences of extreme poverty and the relatively academic approach to the assessment and treatment of mental illness by professionals. This is, of course, an issue that is not peculiar to Mexico, and bears on a critical aspect of the theme addressed by all our contributors.

\title{
The high cost of poverty: mental health perspectives from the Caribbean Diaspora
}

\section{Frederick W. Hickling DM MRCPsych(UK) DFAPA}

Professor of Psychiatry, Department of Community Health and Psychiatry, University of the West Indies, Mona, Kingston 7, Jamaica email frederick.hickling@uwimona.edu.jm

\begin{abstract}
'Globalization is an objective reality - underlying the fact that we are all passengers on the same vessel - the planet where we all live.' (Fidel Castro, 2000, p. vii)
\end{abstract}

Caribbean Diaspora has emerged worldwide after 500 years of European colonial exploitation of the Caribbean geopolitical region. This exploitation has a two-tiered social legacy: the 'haves'; and the 'have-nots', characterised by poor educational achievement, underdevelopment and unemployability of the many. The Caribbean Diaspora is a product of ever-increasing fantasies of escape from poverty by migration to greener 'First World' pastures. The complex, contradictory Caribbean society generates a crucible of misery and violence amid opulent wealth and luxury, which requires a burgeoning private and public police and military apparatus for its containment, and an ever-increasing health, mental health and penal correctional system to buttress the casualties of this conflict that is spiralling out of organisational and economic control. This two-tiered society was inherited from the hierarchical legacy of European colonialism. The colonisers existed in a system of high productivity and order, which imposed its will on the colonised, who lived in relative disorganisation and need. The resultant vector of this unequal yoke is the virtual anarchy of present-day Jamaica and other Caribbean territories, characterised by a subculture of violence and increasingly violent crime. The physical, psychological and economic costs of this seeming conundrum are bewildering and unaffordable.

The dialectic relationship between European wealth and African (and other) poverty is inescapable. In a recent study, Nunn (2007) concluded that slavery played an important role in Africa's underdevelopment; for example, the largest numbers of slaves were taken from areas that were most underdeveloped politically at the end of the 19th century and these areas are the most ethnically fragmented today. Without the slave trade, $72 \%$ of Africa's income gap with the rest of the world would not exist today. In a landmark study, Jamaican economist George Beckford (1972) identified that Latin America and the Caribbean, Africa and Asia, popularly described as the 'Third World', although vast in area and rich in resources, do not provide adequate levels of living for their populations. Beckford suggested that the dynamics of underdevelopment - both of the plantation economy and of society - form the basis for 'persistent poverty' for low- and middle-income countries and economies.

There is an increasingly strident discourse that is demanding a contemporary worldwide resolution of this dialectic of underdevelopment. This is inevitable in the global transformation that is required for the resolution of the crisis of global capitalism. A study by Trinidadian economist Eric Williams (1944) established that African slavery was the midwife to industrialisation in Europe and the slave trade was abolished in order to broaden the base of the global market 
for the products of industrialisation. A similar contemporary economic metamorphosis is now demanded for worldwide economic survival (Castro, 2000; Hart, 2007).

\section{Poverty and mental illness in the Caribbean Diaspora}

A plethora of studies have revealed higher risk ratios of schizophrenia in African-Caribbean migrants to the UK, the USA, Canada and Europe, confined mainly to the lower socio-economic classes (Cantor-Graae \& Selten, 2005). However, similar studies in the Caribbean consistently indicated that the incidence of schizophrenia, between 2 and 3 per 10000 persons, is well within the range of those reported in the native populations of Britain and The Netherlands, and globally (Hickling, 2005). In a case-control study (Hickling, 1996), the diagnoses of a sample of 49 White mentally ill immigrants to Jamaica were compared with those among a sample of mentally ill Jamaicans matched for age, gender and social class, who had never migrated. The study showed that White mentally ill immigrants to Jamaica did not develop schizophrenia at a higher rate than the nativeborn, contrary to the finding of Cochrane \& Bal (1987) of consistently increased rates of schizophrenia in immigrant populations worldwide. This Jamaican study indicated White first-generation migration to the Caribbean was characterised by immediate and marked upward social mobility, a factor which rarely, if ever, occurs for immigrants, whether Black or White, to White majority higher-income countries.

A study of 36 condemned murderers (Hickling et al, 1976) in the Jamaican penal system in 1976 indicated that 83\% had originated from very low socio-economic developmental conditions. There were significantly more Jamaican murderers with 'superior' and 'very superior' IQs in this cohort than would be expected in the normal population. Thus, a very high proportion of Jamaican men with exceptional intellectual functioning end up in a life of crime and murder owing to their early poverty and educational and social deprivation. Jamaican society suffers a dual consequence: it loses some of its brightest men to a life of crime, and so has to expend significant resources on policing and correctional facilities to contain these brightest minds; and it is deprived of these superior intellects in its conventional productive capacity. Instead, they lead the wave of violent crime in Jamaica. The hidden costs of poverty have become the burgeoning costs of criminal violence and social containment.

It is suggested that the political/economic system in postcolonial countries of the Caribbean engenders severe mental illness in the poorest native-born socio-economic classes, but protects White immigrants from the social stress of migration; contrarily, the political structure of White 'First World' countries seems to create psychosocial stress factors that predispose to the development of schizophrenia in Caribbean migrants. It is advanced that existing poverty in people of the Caribbean Diaspora follows the ravages of indigenous genocide and African slavery in the Caribbean, and has emerged as a dialectic antipode of European colonisation and wealth creation that has now become socio-economically unaffordable. O'Higgins (2001) suggests that an unbalanced labour demand structure exists in low-income countries like Jamaica, where the pattern of unemployment indicates that the jobs being generated by current development strategies call for relatively low skill levels, which contrasts starkly with the characteristics and aspirations of young people who are entering the labour market with some secondary schooling and who are aspiring to higher-skilled or white-collar jobs. He suggests that countries such as these need to shift production to a more advanced technological level, both for future economic growth and for job creation.

\section{Conclusions}

The sobering challenges encountered in the analysis of the historical and sociological antecedents of the high and hidden cost of poverty require the development of a new vision of the psychology of economic deprivation and suffering being experienced by low- and middle-income countries and new paradigms for their resolution. The evidence indicates that poverty has become too costly to maintain for any society, and that radical dialectical transformation of the distribution and delivery of wealth are required for sustainable development and the resolution of the harsh problems of environmental degradation, migration, criminality and violence being experienced worldwide. For small Caribbean states like Jamaica, radical new institutional approaches to education and psychological transformation of the burgeoning youthful population, and especially the youth 'at risk' (Hickling, 2007), must become a sine qua non for governments and civic society, which must drive a vision for survival and development for all in the future.

\section{References}

Beckford, G. (1972) Persistent Poverty. Underdevelopment in Plantation Economies of the Third World. Oxford University Press.

Cantor-Graae, E. \& Selten, J. P. (2005) Schizophrenia and migration: a meta-analysis and review. American Journal of Psychiatry, 162, 12-24.

Castro, F. (2000) Capitalism in Crisis. Globalization and World Politics Today. Ocean Press.

Cochrane, R. \& Bal, S. S. (1987) Migration and schizophrenia: an examination of five hypotheses. Social Psychiatry and Psychiatric Epidemiology, 22, 181-191.

Hart, S. L. (2007) Capitalism at the Crossroads. Aligning Business, Earth and Humanity. Wharton School of Publishing.

Hickling, F. W. (1996) Psychopathology of white mentally ill migrants to Jamaica. Journal of Molecular and Chemical Neuropathology, 28, 261-267.

Hickling, F. W. (2005) The epidemiology of schizophrenia and other common mental health disorders in the English-speaking Caribbean. Revista Panamericana de Salud Pública, 18, 256-262.

Hickling, F. W. (2007) Introduction - building a national youth rescue movement. In Dream a World. CARIMENSA and the Development of Cultural Therapy in Jamaica (ed. F. W. Hickling), pp. 1-4. CARIMENSA Publications.

Hickling, F. W., Knight, F., Doorbar, R., et al (1976) Report of a Psychosociological Investigation of the 36 Condemned Men at the St Catherine District Prison and the Causes of the 26th December Demonstration by 26 of Those Men (the Barnett Report). Government of Jamaica.

Nunn, N. (2007) Historical legacies: a model linking Africa's past to its current underdevelopment. Journal of Development Economics, 83, 157-175.

O'Higgins, N. (2001) Youth Unemployment and Employment Policy: A Global Perspective. International Labour Organisation. Available at http://www.yesweb.org/gkr/res/bg.govpol.ta.doc (last accessed January 2009).

Williams, E. (1944) Capitalism and Slavery. University of North Carolina Press. 